\title{
Estimates of blood pressure variability obtained in different contexts are not interchangeable
}

\author{
Stefano Omboni ${ }^{1,2}$
}

Received: 10 September 2021 / Accepted: 16 September 2021 / Published online: 14 October 2021

(c) The Japanese Society of Hypertension 2021

In their study, Boubouchairopoulou and coworkers demonstrate that blood pressure variability (BPV) is not interchangeable when assessed in the office, at home, or under ambulatory conditions [1]. Office BPV was lower than home BPV, and ambulatory BPV was higher than home BPV. Correlations and agreement between office and out-of-office BPV were weak and only marginally stronger between out-of-office measures. No BPV index demonstrated clear superiority. Regardless of the measure used for estimating BPV and the context (office, home, or ambulatory condition), significant determinants of higher BPV were female sex, increased age, elevated body mass index, cigarette smoking, and increased systolic BP.

The finding that short-term, mid-term, and long-term fluctuations are only weakly interrelated is not new. Measurements taken in the office, at home, or under ambulatory conditions reflect different situations and are affected by different pathophysiological, clinical, and behavioral factors that may influence cardiovascular system function (Fig. 1). Consequently, BPVs measured in different contexts do not reflect the same phenomenon. The value of the present work is the comparison of all three measures in the same subjects. The study adds and confirms two previous studies based on a smaller sample of subjects with different characteristics in which a less robust methodology for estimating BPV was used [2, 3].

Despite the poor agreement of BPV estimates between settings, the magnitude of the correlation was similar for the different measures of BPV (standard deviation or SD, coefficient of variation or $\mathrm{CV}$, and variability independent

Stefano Omboni

stefano.omboni@iitelemed.org

1 Clinical Research Unit, Italian Institute of Telemedicine, Varese, Italy

2 Department of Cardiology, Sechenov First Moscow State Medical University, Moscow, Russian Federation of mean or VIM). Using the same analytical approach in the three settings allowed excluding potential bias effects of different methodologies applied to the calculation of BPV. Indeed, the methodology for calculating BPV is highly heterogeneous in various studies, and currently, there is no consensus on how to best measure BPV. Although the authors did not attempt to perform correlation analysis between BPV measures within each context, we may assume that the interrelation was high, and thus the different estimates may provide similar information in the same context. This hypothesis is suggested from studies linking BPV with an increased risk of adverse cardiovascular outcomes and mortality. According to these prognostic studies, different indices of BPV appear to predict outcome to a relatively similar extent, irrespective of the type of calculation employed (Table 1) [4-12].

Despite its several merits, the paper of Boubouchairopoulou and coworkers is not exempt from some flaws. The office BP measurement was accomplished for most subjects via auscultatory measurement using a mercury sphygmomanometer. In only $15 \%$ of subjects was office BP measured with the same oscillometric technology used to measure home and ambulatory BP. Such an approach may have negatively affected the estimation of office BPV. As the digit preference phenomenon may influence auscultatory BP measurement, this may have contributed to blunting the extent of BP variations. Oscillometric BP measurement represents a more objective BP measurement and provides more realistic estimates of BPV: using the same oscillometric technology in the three settings would have rendered the results more robust.

BP measurements were made following the European Society of Hypertension recommendations [13]. However, the accuracy of BPV estimation is highly dependent on the number of measurements used for analysis. Although the median number of measurements obtained over the $24 \mathrm{~h}$ for the whole sample $(n=68)$ complied with current recommendations [14], some patients barely had a minimum number of readings (lower interquartile range in the whole 




Fig. 1 Major types of blood pressure variability and their main determinants. BPV blood pressure variability

Table 1 Risk of all-cause and cardiovascular mortality, and cardiovascular events according to the type of systolic blood pressure variability in major population studies and meta-analyses

\begin{tabular}{|c|c|c|c|c|c|c|c|c|c|c|c|c|}
\hline \multirow[t]{2}{*}{ Author (year) } & \multirow{2}{*}{$\begin{array}{l}\text { Type } \\
\text { of study }\end{array}$} & \multirow[t]{2}{*}{ Type of BPV } & \multirow[t]{2}{*}{ Measure of BPV } & \multirow{2}{*}{$\begin{array}{l}\text { Overall no. of } \\
\text { subjects }\end{array}$} & \multirow{2}{*}{$\begin{array}{l}\text { Mean or median follow- } \\
\text { up (years) }\end{array}$} & \multirow{2}{*}{$\begin{array}{l}\text { Type of } \\
\text { population }\end{array}$} & \multicolumn{2}{|c|}{ All-cause mortality } & \multicolumn{2}{|c|}{ Cardiovascular mortality } & \multicolumn{2}{|c|}{ Cardiovascular events } \\
\hline & & & & & & & $\begin{array}{l}\text { No. } \\
\text { studies }\end{array}$ & OR $(95 \% \mathrm{CI})$ & $\begin{array}{l}\text { No. } \\
\text { studies }\end{array}$ & OR $(95 \% \mathrm{CI})$ & $\begin{array}{l}\text { No. } \\
\text { studies }\end{array}$ & OR $(95 \% \mathrm{CI})$ \\
\hline $\begin{array}{l}\text { Stevens (2016) } \\
\text { [4] }\end{array}$ & MA & Short-term ${ }^{*}$ & $\mathrm{SD}, \mathrm{ARV}$ & 34,759 & $4.4-12.3$ & Mixed & 3 & $1.10(1.01,1.20)$ & 4 & $1.12(1.01,1.25)$ & 2 & $1.06(1.00,1.13)$ \\
\hline $\begin{array}{l}\text { Stevens (2016) } \\
\text { [4] }\end{array}$ & MA & Short-term $^{* *}$ & $\mathrm{SD}, \mathrm{CV}, \mathrm{ARV}$ & 36,005 & $4.4-12.3$ & Mixed & 4 & $1.11(1.04,1.18)$ & 4 & $1.12(1.01,1.25)$ & 2 & $1.06(1.00,1.13)$ \\
\hline $\begin{array}{l}\text { Kikuya (2008) } \\
{[5]}\end{array}$ & OS & Mid-term & SD & 2455 & 11.9 & General & 1 & $1.18(1.07,1.31)$ & 1 & $1.20(1.02,1.40)$ & & NR \\
\hline $\begin{array}{l}\text { Hashimoto } \\
\text { (2012) [6] }\end{array}$ & OS & Mid-term $^{* * *}$ & SD & 902 & 13.1 & General & 1 & $1.06(0.93,1.20)$ & 1 & $1.13(0.90,1.40)$ & & NR \\
\hline $\begin{array}{l}\text { Johansson } \\
\text { (2012) [7] }\end{array}$ & OS & Mid-term & SD & 1866 & 7.8 & General & 1 & $1.05(1.00,1.11)$ & 1 & $1.02(0.98,1.07)$ & & NR \\
\hline $\begin{array}{l}\text { Schutte (2012) } \\
\text { [8] }\end{array}$ & OS & Mid-term & VIM & 2944 & 12.0 & General & 1 & $1.00(0.91,1.10)$ & 1 & $1.11(0.97,1.27)$ & 1 & $1.05(0.96,1.15)$ \\
\hline $\begin{array}{l}\text { Schutte (2012) } \\
{[8]}\end{array}$ & OS & Mid-term & ARV & 2944 & 12.0 & General & 1 & $1.03(0.93,1.13)$ & 1 & $1.08(0.94,1.25)$ & 1 & $1.08(0.98,1.19)$ \\
\hline $\begin{array}{l}\text { Hoshide (2018) } \\
\text { [9] }\end{array}$ & OS & Mid-term & VIM & 4231 & 4.0 & General & & NR & & NR & 1 & $1.32(1.15,1.52)$ \\
\hline $\begin{array}{l}\text { Diaz (2014) } \\
{[10]}\end{array}$ & MA & Long-term & SD & 18,184 & $2.0-7.1$ & Mixed & 4 & $1.20(1.05,1.36)$ & 5 & $1.22(1.09,1.35)$ & 5 & $1.12(0.98,1.28)$ \\
\hline Tai (2015) [11] & MA & Long-term & SD & 77,299 & 6.3 & Mixed & 6 & $1.03(1.02,1.04)$ & 2 & $1.10(1.02,1.17)$ & & NR \\
\hline Tai (2015) [11] & MA & Long-term & $\mathrm{CV}$ & 77,299 & 6.3 & Mixed & 5 & $1.04(1.02,1.06)$ & 2 & $1.01(0.99,1.03)$ & 2 & $1.05(1.00,1.10)$ \\
\hline Tai (2015) [11] & MA & Long-term & VIM & 77,299 & 6.3 & Mixed & 1 & $1.00(0.97,1.03)$ & 1 & $1.03(0.99,1.09)$ & 1 & $1.02(0.99,1.05)$ \\
\hline Tai (2015) [11] & MA & Long-term & ARV & 77,299 & 6.3 & Mixed & 1 & $1.02(0.97,1.06)$ & 1 & $1.04(0.97,1.12)$ & 1 & $1.04(0.99,1.09)$ \\
\hline $\begin{array}{l}\text { Wang (2017) } \\
\text { [12] }\end{array}$ & MA & Long-term & $\mathrm{SD}, \mathrm{CV}$ & 107,434 & $2.0-29.3$ & Mixed & 20 & $1.14(1.09,1.18)$ & 13 & $1.18(1.09,1.28)$ & 9 & $1.12(1.05,1.09)$ \\
\hline $\begin{array}{l}\text { Stevens (2016) } \\
{[4]}\end{array}$ & MA & Long-term* & SD & 252,317 & $2.0-12.9$ & Mixed & 4 & $1.15(1.09,1.22)$ & 3 & $1.18(1.09,1.28)$ & 1 & $1.18(1.07,1.30)$ \\
\hline $\begin{array}{l}\text { Stevens (2016) } \\
\text { [4] }\end{array}$ & MA & Long-term ${ }^{* * *}$ & $\begin{array}{l}\text { SD, CV, SR, } \\
\text { RMSE, VIM }\end{array}$ & 278,561 & $2.0-12.9$ & Mixed & 8 & $1.12(1.05,1.20)$ & 6 & $1.15(1.03,1.30)$ & 11 & $1.13(1.04,1.23)$ \\
\hline
\end{tabular}

*Only studies with low risk of bias; ${ }^{* *}$ All studies; ${ }^{* * *}$ Data available only in men

$B P V$ Blood Pressure Variability, CI Confidence Interval, $C V$ Coefficient of Variation, MA Meta-Analysis, OR Odds Ratio, OS Observational Study, RMSE Root Mean Squared Error, SD Standard Deviation, SR Standardized Residual, VIM Variation Independent of mean 
sample $=64)$; this was insufficient to ensure an accurate estimation of BPV, which must ideally be based on readings obtained every 15-20 min, allowing the collection of 72-96 readings [15].

The authors used SD, CV, and VIM as measures of BPV. These are well-acknowledged estimates of BPV with their pros and cons [16]. Notably, CV and VIM, as opposed to $\mathrm{SD}$, are unrelated to the effect of the average and should be preferred in the assessment of BPV. Disappointingly, the authors did not include average real variability (ARV), another widely used and studied measure of BPV independent of the mean. With SD and CV (as opposed to VIM, which relies on a statistical analysis), ARV can be easily calculated, and it shows a strong association with the progression of subclinical organ damage and cardiovascular events [17].

Finally, as correctly acknowledged by the authors, some crucial factors, such as physical activity and psychosocial or social factors known to potentially affect the magnitude of $\mathrm{BP}$ variations, could not be evaluated. These factors must be considered in future studies.

In conclusion, the study of Boubouchairopoulou and coworkers has the merit of demonstrating for the first time that BPV measured in the office, at home, and in ambulatory conditions provides different information. Hence, estimates of BP variations observed in different contexts should be considered equally helpful in providing a comprehensive picture of BP control in an individual patient. Of course, the lack of standard reference values for BPV and high-quality longitudinal data requires caution in interpreting the value of BPV.

\section{Compliance with ethical standards}

Conflict of interest The author declares no competing interests.

Publisher's note Springer Nature remains neutral with regard to jurisdictional claims in published maps and institutional affiliations.

\section{References}

1. Boubouchairopoulou N, Ntineri A, Kollias A, Destounis A, Stergiou GS. Blood pressure variability assessed by office, home, and ambulatory measurements: comparison, agreement, and determinants. Hypertens Res. 2021. https://doi.org/10.1038/ s41440-021-00736-9. Online ahead of print.

2. Juhanoja EP, Niiranen TJ, Johansson JK, Puukka PJ, Jula AM. Agreement between ambulatory, home, and office blood pressure variability. J Hypertens. 2016;34:61-67.
3. Abellán-Huerta J, Prieto-Valiente L, Montoro-García S, Abellán-Alemán J, Soria-Arcos F. Correlation of blood pressure variability as measured by clinic, self-measurement at home, and ambulatory blood pressure monitoring. Am J Hypertens. 2018;31:305-12.

4. Stevens SL, Wood S, Koshiaris C, Law K, Glasziou P, Stevens RJ, et al. Blood pressure variability and cardiovascular disease: systematic review and meta-analysis. BMJ. 2016;354: i4098.

5. Kikuya M, Ohkubo T, Metoki H, Asayama K, Hara A, Obara T, et al. Day-by-day variability of blood pressure and heart rate at home as a novel predictor of prognosis: the Ohasama study. Hypertension. 2008;52:1045-50.

6. Hashimoto T, Kikuya M, Ohkubo T, Satoh M, Metoki H, Inoue R, et al. Home blood pressure level, blood pressure variability, smoking, and stroke risk in Japanese men: the Ohasama study. Am J Hypertens. 2012;25:883-91.

7. Johansson JK, Niiranen TJ, Puukka PJ, Jula AM. Prognostic value of the variability in home-measured blood pressure and heart rate: the Finn-Home Study. Hypertension. 2012;59:212-8.

8. Schutte R, Thijs L, Liu YP, Asayama K, Jin Y, Odili A, et al. Within-subject blood pressure level-not variability-predicts fatal and nonfatal outcomes in a general population. Hypertension. 2012;60:1138-47.

9. Hoshide S, Yano Y, Mizuno H, Kanegae H, Kario K. Day-by-day variability of home blood pressure and incident cardiovascular disease in clinical practice: The J-HOP Study (Japan Morning Surge-Home Blood Pressure). Hypertension. 2018;71:177-84

10. Diaz KM, Tanner RM, Falzon L, Levitan EB, Reynolds K, Shimbo D, et al. Visit-to-visit variability of blood pressure and cardiovascular disease and all-cause mortality: a systematic review and meta-analysis. Hypertension. 2014;64:965-82.

11. Tai C, Sun Y, Dai N, Xu D, Chen W, Wang J, et al. Prognostic significance of visit-to-visit systolic blood pressure variability: a meta-analysis of 77,299 patients. J Clin Hypertens (Greenwich). $2015 ; 17: 107-15$

12. Wang J, Shi X, Ma C, Zheng H, Xiao J, Bian H, et al. Visit-tovisit blood pressure variability is a risk factor for all-cause mortality and cardiovascular disease: a systematic review and metaanalysis. J Hypertens. 2017;35:10-17.

13. Stergiou GS, Palatini P, Parati G, O'Brien E, Januszewicz A, Lurbe E, et al. 2021 European Society of Hypertension practice guidelines for office and out-of-office blood pressure measurement. J Hypertens. 2021;39:1293-302.

14. Parati G, Stergiou G, O’Brien E, Asmar R, Beilin L, Bilo G, et al. European Society of Hypertension practice guidelines for ambulatory blood pressure monitoring. J Hypertens. 2014;32:1359-66.

15. di Rienzo M, Grassi G, Pedotti A, Mancia G. Continuous vs intermittent blood pressure measurements in estimating 24-hour average blood pressure. Hypertension. 1983;5:264-9.

16. Parati G, Ochoa JE, Lombardi C, Bilo G. Blood pressure variability: assessment, predictive value, and potential as a therapeutic target. Curr Hypertens Rep. 2015; 17:537.

17. Mena LJ, Felix VG, Melgarejo JD, Maestre GE. 24-hour blood pressure variability assessed by average real variability: a systematic review and meta-analysis. J Am Heart Assoc. 2017;6:10. 